\title{
Depression, anxiety, hopelessness and quality of life in users of cocaine/crack in outpatient treatment
}

\author{
Depressão, ansiedade, desesperança e qualidade de vida em usuários de \\ cocaína/crack em tratamento ambulatorial
}

Camila Bosse Paiva, ${ }^{1}$ Isadora Borne Ferreira, ${ }^{2}$ Vera Lúcia Bosa, ${ }^{3}$ Joana Corrêa de Magalhães Narvaez ${ }^{4}$

\begin{abstract}
Objective: To identify symptoms of anxiety, depression, and feelings of hopelessness in patients in outpatient treatment for substance dependency and to test for correlations with various aspects of their quality of life.

Methods: A cross-sectional study of a sample of 25 men in recuperation from substance dependency, selected by convenience. We assessed symptoms of depression (Beck Depression Inventory-II), anxiety (Beck Anxiety Inventory), hopelessness (Beck Hopelessness Scale), and quality of life (World Health Organization Quality of Life instrument-Abbreviated version [WHOQOL-Bref]), and also analyzed sociodemographic profile, substance abuse, and family history. Categorical variables were expressed as frequencies and percentages and quantitative variables as means and standard deviations or as medians and interquartile ranges. We also analyzed Spearman correlations to a $5 \%$ significance level.

Results: The study revealed prevalence rates of $32 \%$ for depression, $24 \%$ for anxiety, and $12 \%$ for hopelessness, at a moderate/severe level. Correlations between Beck scales and WHOQOL-Bref were significant; but impacts differed in the four areas evaluated.

Conclusions: Overall, we observe global negative impacts on subjects' lives, affecting their psychiatric symptoms and quality of life and their relationships and occupational factors to a similar degree. The results show that the lower the scores on these scales, the better the quality of life in some areas, indicating that there is a negative correlation between psychiatric symptoms and quality of life.
\end{abstract}

Keywords: Depression, anxiety, quality of life, cocaine, crack.

\section{Resumo}

Objetivo: Identificar sintomas de ansiedade, depressão e sentimentos de desesperança em pacientes dependentes químicos em tratamento ambulatorial e verificar a existência de correlações com os diferentes âmbitos da qualidade de vida.

Métodos: Estudo transversal com 25 homens em recuperação para dependência química, selecionados por conveniência. Foram avaliados sintomas de depressão (Inventário de Depressão de Beck-II), ansiedade (Inventário de Ansiedade de Beck) desesperança (Escala de Desesperança de Beck) e qualidade de vida (World Health Organization Quality of Life instrument-Abbreviated version [WHOQOL-Bref]), bem como perfil sociodemográfico, uso de substâncias e histórico familiar. Variáveis categóricas foram apresentadas como frequências e percentuais, e variáveis quantitativas, como médias e desvios-padrão ou medianas e intervalos interquartis. Foram utilizadas também correlações de Spearman com nível de significância de 5\%.

Resultados: 0 estudo revelou prevalência de $32 \%$ para depressão, 24\% para ansiedade e $12 \%$ para desesperança, em níveis moderado/grave. As correlações entre os inventários Beck e o WHOQOL-Bref foram significantes; entretanto, os impactos diferiram nos quatro domínios avaliados.

Conclusões: De modo geral, observaram-se prejuízos globais na vida dos sujeitos, tanto frente a sintomas psiquiátricos e qualidade de vida quanto sobre relacionamentos e questões ocupacionais, em níveis semelhantes. Os resultados apontam que, quanto menor a pontuação nesses inventários, melhor a qualidade de vida em alguns domínios, indicando haver correlação negativa entre sintomas psiquiátricos e qualidade de vida. Descritores: Depressão, ansiedade, qualidade de vida, cocaína, crack.

\footnotetext{
1 Programa de Pós-Graduação em Psicologia Clínica, Pontifícia Universidade Católica do Rio Grande do Sul (PUCRS), Porto Alegre, RS, Brazil. 2 Centro de Estudos em Alimentação e Nutrição, Hospital de Clínicas de Porto Alegre, Universidade Federal do Rio Grande do Sul (UFRGS), Porto Alegre, RS, Brazil. ${ }^{3}$ Centro de Estudos em Alimentação e Nutrição, Hospital de Clínicas de Porto Alegre, Universidade Federal do Rio Grande do Sul (UFRGS), Departamento de Nutrição FAMED/UFRGS, Porto Alegre, RS, Brazil. ${ }^{4}$ Centro colaborador em álcool e drogas, Hospital de Clínicas de Porto Alegre (HCPA), Porto Alegre, RS, Brazil. Financial support: Fundo de Incentivo à Pesquisa - Hospital de Clínicas de Porto Alegre (FIPE-HCPA).

Submitted Feb 26 2015, accepted for publication Nov 25 2016. No conflicts of interest declared concerning the publication of this article.

Suggested citation: Paiva CB, Ferreira IB, Bosa VL, Narvaez JCM. Depression, anxiety, hopelessness and quality of life in users of cocaine /crack under outpatient treatment. Trends Psychiatry Psychother. 2017;39(1):34-42. http://dx.doi.org/10,1590/2237-6089-2015-0065
} 


\section{Introduction}

Dependence on psychoactive substances has become a subject of both debate and research in our society and can be characterized as a prominent problem, growing constantly and on a global level. ${ }^{1}$ Research indicates that $22.8 \%$ of the Brazilian population have already taken some type of drug in their lives, $2.9 \%$ have used cocaine and $0.7 \%$ have used crack. ${ }^{2}$ In view of these proportions, it is essential to acquire knowledge and to map the variables around this disorder, as a source of support for development of new and more assertive actions for prevention and treatment of this disease.

Studies show that the main foci of the harm caused by abuse of cocaine and crack are as follows: social and occupational problems; physical, psychic and cognitive effects; and considerable reductions in quality of life. ${ }^{3}$ Furthermore, these individuals have a tendency to become polydrug users - using several drugs concurrently - within which we highlight alcohol abuse. ${ }^{2,4}$ This concurrency is thought to be related to users attempting to neutralize or relieve the symptoms of intoxication or the discomfort caused by abstinence. ${ }^{5}$ However, combined use of these substances creates a new drug, called cocaethylene, which has more potent effects. ${ }^{6}$

Since these people are more likely to develop psychiatric disorders than people who do not take drugs, studies have been conducted to determine the most prevalent psychiatric symptoms in drug users. 7,8 Moreover, it is known that one third of the population that takes psychoactive substances exhibit psychiatric comorbidities. ${ }^{9}$ The most prevalent mental disorders are depression (47.8\%) and anxiety (21.2\%), irrespective of whether users are being treated for their dependence or not. ${ }^{10,11}$ In the presence of comorbidity, the situation is aggravated because mental disorders make managing and treating these users even more difficult, leading to a less optimistic prognosis. ${ }^{12,13}$

It is known that a mental disorder that is not properly treated is one of the main causes of incapacity and reduction of quality of life. ${ }^{10}$ Irrespective of whether it refers to a person who has substance dependency, quality of life is not dependent on a person's culture and encompasses physical as well as psychological elements, social relations, and personal beliefs, and is related to the environment in which they live. ${ }^{11}$ Being the search for health emphasized in the face of mental disorders, the scope of quality of life also receives more evidence, since both (health and quality of life) are related in their broad concepts. ${ }^{14}$

When quality of life was compared between people with and without substance dependence, it was observed that those who were substance dependent exhibited lower scores in almost all of the elements analyzed, providing evidence of the global nature of impairment of their quality of life. ${ }^{15}$ When in treatment, it was found that integration is of fundamental importance to helping improve their perceived quality of life. ${ }^{16}$ Hopelessness can further exacerbate what is already a very difficult constellation of symptoms, but the literature still lacks effective assessment of this issue.

The main aim of this study was to identify symptoms of anxiety, depression, and hopelessness in substance dependence outpatients and to verify whether there are correlations with the different elements of their quality of life.

\section{Methods}

This research was conducted as a cross-sectional study with the aim of verifying psychiatric symptoms and their correlations with quality of life in cocaine and crack users. The project was approved by the Ethics Committee at the Hospital de Clínicas de Porto Alegre (HCPA) under protocol number 14-0153, registered on Plataforma Brasil, and an informed consent form was used with all the subjects, in accordance with current rules on research involving human beings. ${ }^{17}$

The sample comprised 25 male individuals with dependence on cocaine and/or crack who had been discharged from inpatient substance dependence treatment in the Álvaro Alvim Unit (AAU) at the HCPA, a hospital in the south of Brazil, and were receiving outpatient treatment at this same unit. Subject selection was by convenience. Patients were excluded from the study if they were exclusively dependent on alcohol or could not answer the instruments, whether because of major cognitive impairment (clinically verifiable), dementia, or illiteracy.

Data were collected from May to August 2014 at the AAU outpatient clinic, taking due care to protect privacy during collection. Contact was made by telephone, the objective of the study was explained and, if the subject was interested, an appointment was then scheduled to fit the participant's availability. In private sessions, the study was explained in detail, the informed consent form was signed, and the instruments were administered. All interviews were conducted by two residents in Mental Health who were working in the field of substance dependence - a psychologist and a nutritionist - and both were trained in advance to standardize data collection.

Statistical analysis of the data was conducted using the Statistical Package for the Social Sciences (SPSS) 
version 18.0. Categorical variables are expressed as frequencies and percentages and continuous variables as means and standard-deviations or medians and interquartile ranges. Spearman coefficients were used to test for correlations between the Beck scales and the World Health Organization Quality of Life instrumentAbbreviated version (WHOQOL-Bref), to a significance level of $5 \% .^{18}$

The researchers developed a questionnaire specifically for the purpose of collecting demographic data and data on substance use, impairments, and family history, with the aim of optimizing the time available for data collection. The decision was taken to use validated scales for the factors and outcomes investigated in this study.

Socioeconomic characteristics were defined according to the Brazilian Economic Classification Criteria $^{19}$ points system, which is calculated using an instrument that surveys domestic characteristics to differentiate the population. Points are summed to obtain a correspondence between score ranges and economic classification strata, as follows: A, B (1-2), C (1-2) and $D-E$, and each stratum is linked to a monthly household gross income band in Brazilian reais.

The WHOQOL-Bref was chosen to assess the sample's quality of life. Developed by the World Health Organization (WHO) quality of life group with the aim of achieving a psychometric and satisfactory evaluation of subjects' quality of life, it comprises 26 questions. Twenty-four of these are distributed into 4 domains assessing the subject's perceptions of physical, psychological, and environmental elements and social relations and the other two are general questions, one referring to perceived quality of life and the other to satisfaction with own health. ${ }^{20}$

Since the WHO does not recommend using a total score, scores were calculated for each of the four domains, on scales from zero to 100 . These scores are positive scales, in that the higher the score, the better the quality of life in that domain. ${ }^{21}$

The Beck Depression Inventory-II (BDI-II) is an important instrument for assessing depression and it was used in this study to investigate depressive symptoms. The inventory has 21 questions about depressive symptoms in the previous two weeks, and the scores classify them as minimal, mild, moderate, or severe. ${ }^{22}$ The Beck Anxiety Inventory (BAI) was used to verify anxiety, comprising 21 items with components that describe symptoms of anxiety and classify it as minimal, mild, moderate, or severe. ${ }^{23}$

Hopelessness was assessed using the Beck Hopelessness Scale (BHS). This instrument comprises 20 sentences against which the subject checks true or false, critically measuring their pessimist and negative thinking in relation to the future, classifying it as minimal, mild, moderate, or severe hopelessness. ${ }^{23}$

All of these instruments have been translated into Portuguese and validated for the Brazilian population. A cutoff score was used for prevalence descriptions, classifying subjects as symptomatic if they had moderate or severe classifications according to the scales $^{24}$.

Complementary to these, patient records were also used, after due authorization by the institution's Ethics Committee.

\section{Results}

Table 1 lists the main sociodemographic characteristics of the sample of 25 subjects. Their mean age was $41.04 \pm 10.19$ years. As for educational level, they had completed a mean of $9.84 \pm 3.40$ years' schooling, and $32 \%$ had not finished primary school. It was observed that most of the subjects were classified as socioeconomic class $C$ ( 1 and 2 ) according to the Brazilian market research association's Economic Classification Criteria, which indicates that their mean family gross monthly income was from $R \$ 1,277.00$ to $\mathrm{R} \$ 1,865.00$

Table 1 - Description of the sociodemographic data $(n=25)$

\begin{tabular}{lc}
\hline Variable & $\mathbf{n}(\%)$ \\
\hline Race & $20(80)$ \\
White & $2(8)$ \\
Black & $3(12)$ \\
Mixed & \\
Marital status & $16(64)$ \\
Single & $7(28)$ \\
Married or cohabitating & $2(8)$ \\
Divorced & \\
Origin & $21(84)$ \\
State capital & $3(12)$ \\
Countryside & $1(4)$ \\
Coast & \\
Children & $17(68)$ \\
Yes & $3(12)$ \\
Lives alone & \\
Lives with: & $9(36)$ \\
Father & $8(32)$ \\
Mother & $8(32)$ \\
Life partner & \\
Economic class & $2(8)$ \\
A & $9(36)$ \\
B (1-2) & $12(48)$ \\
C (1-2) & $2(8)$ \\
D-E &
\end{tabular}


Several professions were mentioned, but the highest prevalence $(20 \%)$ was of subjects that self-reported as not having a profession. The most often reported occupations were: construction (12\%), IT technician $(12 \%)$, doorman ( $8 \%)$, general services auxiliary $(8 \%)$, and administrative positions ( $8 \%$ ) - of these, only $40 \%$ of the sample was currently working. Of those who were not working, $93.3 \%$ stated they had worked at some point in their lives and $40 \%$ of the whole sample was receiving some sort of social security benefit. The maximum period ever worked for participants who were not currently working was a median of 42 months (1240).

The mean age at first drug experimentation was $14.12 \pm 2.93$ years and mean duration of abuse of some type of substance was $25.28 \pm 9.86$ years. When we compared the first substance taken to the most recent preferred substance, we observed drug substitutions, as shown in Table 2. At the time of data collection, the sample had been abstinent for a median of 90.0 (8548) days.

Table 2 - Description of data on abuse of substances and related problems $(n=25)$

\begin{tabular}{lc}
\hline Details of substance abuse & $\mathbf{n}(\%)$ \\
\hline 1st substance used & \\
Cannabis & $10(40)$ \\
Alcohol & $8(32)$ \\
Tobacco & $6(24)$ \\
Inhalants & $1(4)$ \\
Current substance of & \\
preference & \\
Crack & $14(56)$ \\
Cocaine & $5(20)$ \\
Alcohol & $4(16)$ \\
Cannabis & $2(8)$ \\
Problems due to use & \\
Family & $25(100)$ \\
Work & $23(92)$ \\
Friendships & $20(80)$ \\
Health & $3(12)$ \\
\hline
\end{tabular}

Table 2 also lists the subjects' subjective perceptions of harm resulting from drug use in relation to the domains family, work, friends, and health. The mean number of past admissions was $5.44 \pm 6.838$ per user. Additionally, several health services had been previously visited, such as: psychosocial care center - CAPSad (52\%), Alcoholics and/or Narcotics Anonymous (48\%), therapeutic communities (48\%), Red Cross (32\%) and others $(8 \%)$.
Table 3 lists frequencies of the sample's family history of substance dependence and other psychiatric disorders, and also the prevalence rates of family members receiving treatment. The findings related to other psychiatric disorders besides substance dependence are taken from the institution's patient records, where psychiatric assessment was conducted during inpatient treatment, showing that $44 \%$ had a disorder, breaking down as: depression $45.5 \%$, bipolar affective disorder $36.4 \%$, anxiety disorders (anxiety disorders were grouped according to Diagnostic and Statistical Manual of Mental Disorders, Fifth Edition [DSM-V], such as post-traumatic stress disorder and social phobia) $36.3 \%$, attention deficit hyperactivity disorder $9.1 \%$, and gender identity disorder $9.1 \%$.

All of the subjects were taking psychiatric medication. Prevalence rates for these were as follows: antipsychotics, 76\%; benzodiazepines, 52\%; mood stabilizers, 48\%; antidepressants, 44\%; and antialcohol $12 \%$. The Beck scales identified the following prevalence rates: depression, 32\%; anxiety, 24\%; and hopelessness, $12 \%$. Results for comorbidities are also shown in Table 4.

The results for quality of life domains were as follows: $57.57 \%$ physical, $62.17 \%$ psychological, $66 \%$ social relations, and $60.81 \%$ environmental, where the closer to 100 the better the quality of life. Spearman coefficients were used to test for correlations between Beck Inventory scores and quality of life results, revealing statistically significant associations. These correlations were inverse, i.e. negative, indicating inverse relationships between psychiatric symptoms and quality of life. Specifically, the lower the BDIII score, the better the quality of life in the physical, psychological, and social domains; the lower the BAI score, the better the psychological quality of life domain; the lower the BHS score, the better the psychological and environmental quality of life domains (Table 5).

\section{Discussion}

The sample investigated in this study has the same sociodemographic profile described in previous literature - it is made up of single white men, with children, low educational level, and economic vulnerability. ${ }^{25,26}$ Its prevalence of single men diverges from the south Brazilian population, in which they equate to $44.2 \%,{ }^{27}$ which is lower than the rate observed in this study. These data may be related to this population's difficulty sustaining relationships, because they tend to organize their lives around drug use. ${ }^{25,28}$ 
Depression and quality of life in drug users - Paiva et al.

Table 3 - Description of data on family history of substance dependence and other psychiatric disorders

\begin{tabular}{lccc}
\hline Family & $\begin{array}{c}\text { Substance } \\
\text { dependency }\end{array}$ & $\begin{array}{c}\text { Other psychiatric } \\
\text { disorders }\end{array}$ & Treatment \\
\hline Father & $11(44)$ & $1(4)$ & $3(12)$ \\
Mother & $2(8)$ & $3(12)$ & $2(8)$ \\
Siblings & $10(40)$ & $6(24)$ & $2(8)$ \\
Maternal grandparents & $1(4)$ & $2(8)$ & $0(0)$ \\
Paternal grandparents & $1(4)$ & $1(4)$ & $1(4)$ \\
Maternal uncles/aunts & $3(12)$ & $0(0)$ & $0(0)$ \\
Paternal uncles/aunts & $3(12)$ & $0(0)$ & $0(0)$ \\
\hline
\end{tabular}

Data presented as n (\%).

Table 4 - Results for combinations of psychiatric symptoms of depression, anxiety, and hopelessness

\begin{tabular}{lc}
\hline Symptom & $\mathbf{n}(\mathbf{\%})$ \\
\hline Absence of symptoms & $14(56)$ \\
Only anxiety or hopelessness & $3(12)$ \\
Only depression & $4(16)$ \\
$\begin{array}{l}\text { Depression + anxiety or } \\
\text { hopelessness }\end{array}$ & $2(8)$ \\
$\begin{array}{l}\text { Depression + anxiety }+ \\
\text { hopelessness }\end{array}$ & $2(8)$ \\
\hline
\end{tabular}

Table 5 - Correlations between World Health Organization Quality of Life instrument-Abbreviated version (WHOQOLBref) scores and the Beck scales

\begin{tabular}{lcc}
\hline WHOQOL-Bref & $\mathbf{r}^{*}$ & p-value \\
\hline Physical & -0.604 & 0.001 \\
BDI-II & -0.483 & 0.014 \\
BAI & -0.428 & 0.033 \\
BHS & & \\
Psychological & -0.543 & 0.005 \\
BDI-II & -0.548 & 0.005 \\
BAI & -0.538 & 0.006 \\
BHS & & \\
Social Relations & -0.492 & 0.013 \\
BDI-II & -0.248 & 0.232 \\
BAI & -0.330 & 0.107 \\
BHS & & \\
Environmental & -0.248 & 0.231 \\
BDI-II & -0.362 & 0.076 \\
BAI & -0.563 & 0.003 \\
BHS & &
\end{tabular}

BAI = Beck Anxiety Inventory; BDI-II = Beck Depression InventoryII; BHS = Beck Hopelessness Scale; WHOQOL-Bref $=$ World Health Organization Quality of Life instrument-Abbreviated version.

* Spearman correlation coefficient.

The mean age of these subjects is older than is reported in the literature - most studies refer to young adults, while our sample includes mature adults. ${ }^{29}$ This may be attributable to the context of several attempts at abstinence and relapses (as reported by the sample) or, also, to long periods of uninterrupted use, followed by many losses and suffering, which is a trigger and an aid in motivation to adhere to treatment and maintain abstinence. ${ }^{30}$

The high rate of absence from the labor market goes beyond rates in the current literature, ${ }^{3}$ which reports lower frequencies. It is supposed that the high figures are due to the recent discharge from inpatient treatment (which indicates the severity of the relationship to the substance) or to receiving benefits. It is important to highlight here that unemployment can aggravate the situation of substance dependent subjects, because of social vulnerability and secondary problems, such as engaging in crime to support continued use. ${ }^{1}$

The individuals in our sample reported a profile of evolution through drug use and substitution, since the first substances used were different from their current preferences. This data matches the literature, highlighting cannabis and alcohol as the main substances of first use, followed by their substitution by cocaine and/or crack. ${ }^{31}$ Nevertheless, this progression does not nullify the desire for other substances, and alcohol is commonly combined with use of these others. Some studies discuss the comorbid use of substances, describing this conduct as characteristic of cocaine and crack users. ${ }^{2,4}$

This behavior may occur exactly because of the fact that depressant substances, such as alcohol, apparently minimize the symptoms caused by stimulating drugs. 5,32 However, data suggest that when cocaine is used with alcohol a new substance is formed, cocaethylene, potentiating the effect of cocaine, enhancing euphoria ${ }^{6}$ and intensifying toxicity. ${ }^{33}$ This combined administration increases the loss of control over consumption, the social problems, and the violent behavior, and can be the foundation for severe clinical conditions. ${ }^{34}$

There was evidence of problems with family, work, friends, and health, indicating deterioration in subjects' lives globally - results that agree with the literature. ${ }^{25}$ Similar data is also found on family problems, highlighting how strongly substance dependence negatively impacts on interpersonal relationships. ${ }^{25,35}$ 
If we consider that cocaine and crack are stimulant substances, that their use can trigger violent behavior due to reduction of one's ability to control impulses, and that they can enhance feelings of persecution, ${ }^{36}$ these effects can form the basis of a hypothesis for the accumulation of these negative impacts. This shows the importance of involving in treatment family members or people that live near to the user, for a psychoeducational approach and biopsychosocial support, which should benefit the treatment and facilitate the drug user's recovery. ${ }^{37}$

There was considerable prevalence of paternal substance dependence, which was repeated among siblings and of other psychiatric disorders, mostly untreated, as described in the literature 1 that indicates that a little over half of the subjects had family history of substance dependence. From these findings, we can consider transgenerational and genetic aspects, and risk factors, i.e., to what extent can the fact of growing up in an environment with these characteristics generate models for future behavioral standards and lead to development of biopsychosocial problems? ${ }^{28}$

Beck inventory results also agreed with the data obtained from patient records, providing evidence of symptoms of depression, anxiety, and hopelessness, corroborating studies by Watkins et al. ${ }^{10}$ and Kessler et al., ${ }^{11}$ which indicated major prevalence rates of these symptoms in people with substance dependence, sometimes even in combination, since we observed that some subjects exhibited depression alongside anxiety or hopelessness, in addition to all the other symptoms. Some disorders may be prior to substance use, since drug use can occur as an attempt to alleviate the symptoms of psychiatric disorders which would make arousal of residual symptoms due to the possible presence of the comorbidity more likely. ${ }^{38}$ However, it is important to point out that depression and anxiety are common in this population, because abuse of drugs can trigger mood imbalances. ${ }^{39}$

We should also highlight the importance of a complete diagnosis, observing the presence or absence of comorbidities, since conditions that are not correctly treated can lead to abandonment of treatment due to the severity that these combinations can attain.

One characteristic particular to this sample is that all of the subjects were on medication and yet, even with this drug therapy, symptoms were easily observed. The most prevalent class of medication was antipsychotics, very often used to deal with craving, although there is no consistent scientific evidence that proves this therapeutic indication. ${ }^{40}$ Nonetheless, a current study conducted in a Brazilian hospital ${ }^{41}$ has also verified antipsychotic drugs as frequently used in the treatment of people with substance dependence.
A study by Moreira et al. ${ }^{15}$ suggests that psychiatric disorders can impact people's quality of life - as we also observed. According to the quality of life scores, the domain that was most negatively affected was the physical, followed by the environmental, and psychological domains. The most preserved domain, in comparison with the others, was social relations.

On the depression scale results, the physical, psychological, and social domains were all significant, similar to what was observed on the anxiety scale, where the psychological domain was also significant. On the hopelessness scale, the psychological domain was once again significant, as was the domain related to environmental elements. These findings agree with a study by Escudeiro et al., also using the WHOQOL-Bref, which detected associations between psychopathologic symptomology and quality of life in people with substance dependence. ${ }^{16}$

Analyzing the depression inventory, the relationship with physical, psychological, and social of quality of life is in line with the disorder's symptomology, which indicates characteristics of depressed mood, decrease or loss of pleasure in activities, and sensations of uselessness and guilt. The significance of the physical domain is much better explained by fatigue, loss of energy, and psychomotor problems. ${ }^{42} \mathrm{~A}$ correlation between depression and quality of life was also described in a study by Marcon et al. ${ }^{43}$ which assessed people with substance dependence, indicating a strong relationship between the two. They used a different instrument to the WHOQOL-Bref to assess quality of life and the domains with the strongest correlations were psychic alterations, feeling of sadness, anxiety, decreased energy for daily activities, and the will to transform decisions into actions.

The literature describes characteristics of the relationship of depression and substance dependence that may be related to what we have observed, since it is unknown which disorder came first. There have already been descriptions of the possibility that several attempts at self-medication by drug use to confront depression can occur, because subjects who are more depressed can find false benefits in the effects of crack and cocaine. ${ }^{25,44}$ The inverse has also been described, i.e. depression due to the psychopharmacological effects of these substances; initial mood elevation followed by depressant effects, which could be aggravated by excessive and recurrent use, because the serotonergic system is affected. ${ }^{39}$

It was observed that the social domain was only significant for the depression scale, suggesting that most subjects preserve some social bonds. This significance is understandable, because depressed subjects have a 
certain difficulty with recognizing the bonds they have and manage to enjoy social contact. ${ }^{42}$ Thus, since the WHOQOL-Bref is a subjective questionnaire, it reveals subjects' perceptions of their lives.

In scales that had no relation to the social domain, we understand that the fact that they had been discharged from impatient treatment (where family life and recovery of weakened relationships are prioritized) and were in outpatient treatment at the same service may have facilitated a move towards problem solution in this respect, because, previously, this same population reported already having lost family relationships because of substance dependence. Another hypothesis for the non-significance of the social domain is the fact that they were circulating in environments offering social life, and thus had the opportunity to relate socially with several people.

The correlation observed between anxiety and the psychological domain of quality of life is understood in a similar way as that for depression, since fear, excessive anxiety, and behavioral imbalances are all seen in anxiety too. ${ }^{42}$ The relationship between anxiety and the psychological domain agrees with what was observed by Lima, who also showed correlations with this domain when assessing cocaine users. ${ }^{45}$

Analysis of the hopelessness scale showed relationships both with the psychological domain and with the domain that covers environmental elements of quality of life. A previous study that assessed hopelessness in cocaine users did not find significant results ${ }^{46}$ in contrast with the results we report here. One hypothesis for this disagreement lies in the differences between samples - whereas the study conducted in the 1990s assessed cocaine users, here we include crack users and polydrug users, so we suppose that the impact of crack and/or multiple drugs may be worse.

With regard to the relationship between environment and hopelessness, we believe that financial and leisure elements are among those that may suffer a negative impact, related to the reformulation of life that tends to occur when there is dedication to treatment. After all, many habits need to be reorganized and many behaviors need to be modified so that the patient can sustain abstinence - modifications that can initially rupture previous routines. Moreover, matters of access to health services - an item assessed in this domain of quality of life - may have improved a little, since these subjects are in weekly follow-up.

The correlation between BHS scores and the psychological domain may suggest that these people, although receiving treatment, present themselves as pessimistic and vulnerable, since the BHS aims to measure risk behaviors through the dimension of pessimism about the future ${ }^{47}$ and hopelessness can be an indicator between depression and suicide. ${ }^{48}$

Observing the results of the Beck scales and their relationships to the WHOQOL-Bref, it was noted that in this study these instruments managed to complement each other when measuring similar constructs - for example, where the BDI was statistically significant for physical, psychological and social losses of quality of life. However, it is not possible to measure the impact of one domain on another.

Although some studies highlight deterioration of quality of life in drug users, there are also many contradictory results. Silveira et al. ${ }^{49}$ assessed people with substance dependence and concluded that they can have a good level of quality of life and a positive perception of health, even with all the conditions implicit to drug use. Nonetheless, they make a reservation with relation to how strongly socioeconomic influences and family assistance can interfere with this result.

This study has some limitations. The data presented here cannot be generalized to the general public of cocaine and crack users, because our subjects were receiving treatment and it can be inferred that they were willing to change. Furthermore, our sample is entirely made up of men. Since all the subjects in the sample were abstinent, medicated, and receiving treatment, it is understood that this can introduce bias to the symptoms assessed here. However, this is understood as a conservative bias, since even when receiving treatment and in abstinence the symptoms were observable. Moreover, it is imagined that people who are not receiving treatment can present even more worrying and intense characteristics.

The study sample could be considered small. Nevertheless, this is a very specific population: men who had been discharged from inpatient treatment, who were attending outpatient treatment, and with dependence on cocaine and/or crack. We highlight that it was not one of the study objectives to assess cognitive deficits in depth, although we understand the importance of determination of this characteristic in this population. Nevertheless, we only performed a clinical assessment to identify exclusion criteria, such as cognitive deficits, that could prevent patients from understanding the instruments used and answering them.

We therefore understand that there are restrictions preventing more complex associations in this study. Since it is a cross-sectional design, we were able to make associations between some symptoms and the domains of quality of life, but we cannot state whether symptoms were present prior to the substance dependence or if they came after it. Although we 
aimed to assess cocaine and crack users, it is typical of this population to use multiple substances, so some of our subjects used other drugs in addition to cocaine and crack.

\section{Conclusion}

This study intended to evaluate people with substance dependence during the recovery process, investigating their sociodemographic profiles, use of substances, family history and, most importantly, the existence of psychiatric symptoms and their impact on the domains of quality of life, where we found significant associations. Moreover, the impact on family relationships and the progression of substances use were also considered.

The data obtained show an early mean age of initial substance use, highlighting the need for an approach combining prevention and treatment, because it is possible that when they were young these people tended to experience a context of exposure to several vulnerabilities. In addition to the young age, we also observed a progression of drug use and a high prevalence of unemployment, which reinforces the urgency of the need for psychoeducation about the disorder, its consequences, and characteristics. Other prominent issues were the elements linked to these subjects' families - a high frequency of substance dependence and other psychiatric disorders, as well as lost family relationships due to substance dependence.

We highlight the findings of considerable psychiatric symptoms of depression, anxiety, and hopelessness, which had significant relationships with quality of life. The depression scale had more statistically significant domains than the others, involving the physical, psychological, and social domains. For the anxiety scale, only the psychological domain was significant. The hopelessness scale also had a significant relationship with the psychological domain of quality of life, and also with the domain that assessed environmental elements.

These data indicate that symptoms of depression, anxiety, and hopelessness impact on the psychological domain when quality of life is analyzed for this population. Since we used an instrument that assesses quality of life subjectively, we can see that the alteration in psychological symptomology reflected on quality of life, i.e., the mental state affected both instruments. These data confirm that if there are psychological disorders, such as anxiety, depression, and hopelessness, they negatively influence this population's quality of life.

Since substance dependence is a disorder in which there is a lot of resistance to starting and maintaining treatment, we believe that these data may contribute to a more assertive approach, considering that sometimes there will be some domains of quality of life that are harmed when related to the symptoms found. Furthermore, the better we know the public we work with, the more we can work on it.

Given the complex variables involved in this disorder, investing in new studies, particularly prospective ones that could improve knowledge about these subjects over the long term should contribute to actions for prevention, maintenance, and recovery in this population.

\section{References}

1. Capristrano FC, Ferreira ACZ, Silva TL, Kalinke LP, Maftum MA. Perfil sociodemográfico e clínico de dependentes químicos em tratamento: análise de prontuários. Esc Anna Nery. 2013;17:234-41.

2. Carlini EA, Galduróz JC, Noto AR, Carlini CM, Oliveira LG, Nappo SA, et al. II Levantamento domiciliar sobre o uso de drogas psicotrópicas no Brasil: estudo envolvendo as 108 maiores cidades do país, 2005. São Paulo: CEBRID/UNIFESP; 2007.

3. Oliveira LG, Nappo SA. [Characterization of the crack cocaine culture in the city of São Paulo: a controlled pattern of use]. Rev Saude Publica. 2008;42:664-71.

4. Noto AR, Galduróz JC, Nappo SA, Fonseca AM, Carlini CMA, Moura YG, et al. Levantamento nacional sobre uso de drogas entre crianças e adolescentes em situação de rua nas 27 capitais brasileiras - 2003 [Internet]. 2003 [cited 2017 Jan 05]. cebrid.com. $\mathrm{br} / \mathrm{wp}$-content/uploads/2012/10/Levantamento-Nacional-sobreo-Uso-de-Drogas-entre-Crian\%C3\%A7as-e-Adolescentes-emSitua\%C3\%A7\%C3\%A3o-de-Rua-nas-27-Capitais-Brasileiras-2003. pdf

5. Gossop M, Manning V, Ridge, G. Concurrent use and order of use of cocaine and alcohol: behavioural differences between users of crack cocaine and cocaine powder. Addiction. 2006;101:1292-8.

6. Scheffer, M, Pasa, GG, de Almeida RMM. Dependência de álcool, cocaína e crack e transtornos psiquiátricos. Psic Teor e Pesq. 2010;26:533-41.

7. Ribeiro M, Laranjeira R. Tratamento do usuário de crack. $2^{\mathrm{a}}$ ed. Porto Alegre: Artmed; 2012.

8. Hess ARB, de Almeida RMM, Moraes AL. Comorbidades psiquiátricas em dependentes químicos em abstinência em ambiente protegido. Estud Psicol (Natal). 2012;17:171-8.

9. Associação Brasileira de Psiquiatria. Abuso e dependência de múltiplas drogas [Internet]. 2012 Oct 15 [cited 2014 Nov 17]. diretrizes. amb.org.br/_BibliotecaAntiga/abuso_e_depend\%C3\%AAncia_de_ multiplas_drogas.pdf

10. Watkins KE, Hunter SB, Wenzel SL, Tu W, Paddock SM, Griffin A, et al. Prevalence and characteristics of clients with co-occurring disorders in outpatient substance abuse treatment. Am J Drug Alcohol Abuse. 2004;30:749-64.

11. Paim Kessler FH, Barbosa Terra M, Faller $S$, Ravy Stolf A, Carolina Peuker A, Benzano D, et al. Crack users show high rates of antisocial personality disorder, engagement in illegal activities and other psychosocial problems. Am J Addict. 2012;21:370-80.

12. Hopwood CJ, Morey LC, Skodol AE, Sanislow CA, Grilo CM, Ansell $E B$, et al. Pathological personality traits among patients with absent, current, and remitted substance use disorders. Addict Behav. 2011:36:1087-90.

13. Swendsen J, Conway KP, Degenhardt L, Glantz M, Jin R, Merikangas $K R$, et al. Mental disorders as risk factors for substance use, abuse and dependence: results from the $10 \square$ year follow $\square$ up of the National Comorbidity Survey. Addiction. 2010;105:1117-28.

14. Canavarro MC, Pereira M, Moreira H, Paredes T. Qualidade de vida e saúde: aplicações do WHOQOL. Lisboa: Instituto Politécnico de Lisboa; 2010.

15. Moreira TC. Qualidade de vida em usuários de substâncias psicoativas, familiares e não usuários por meio do WHOQOL-BREF. Cienc Saude Coletiva. 2013;18:1953-62.

16. Escudeiro R, Lamachã S, Freitas A, Silva H. Qualidade de vida e toxicodependência. Toxicodependências. 2006;12:65.

17. Brasil, Ministério da Saúde (MS), Conselho Nacional de Saúde. Resolução no 466/12. 2012 [cited 2017 Jan 05]. http://conselho. 
saude.gov.br/resolucoes/2012/Reso466.pdf

18. Conover WJ. Practical nonparametric statistics. 2nd ed. New York: Wiley; 1980.

19. Associação Brasileira de Empresas de Pesquisa (ABEP). Critério de classificação econômica Brasil [Internet]. 2014 [cited 2014 Nov 17]. abep.org/codigos-e-guias-da-abep

20. Fleck MP, Louzada S, Xavier M, Chachamovich E, Vieira G, Santos $L$, et al. [Application of the Portuguese version of the abbreviated instrument of quality life WHOQOL-bref]. Rev Saude Publica. $2000 ; 34: 178-83$.

21. Development of the World Health Organization WHOQOL-BREF quality of life assessment. The WHOQOL Group. Psychol Med. 1998;28:5518.

22. Gomes-Oliveira MH, Gorenstein C, Lotufo Neto F, Andrade LH, Wang YP. Validation of the Brazilian Portuguese version of the Beck Depression Inventory-II in a community sample. Rev Bras Psiquiatr. 2012;34:389-94.

23. Cunha JA. Manual da versão em português das escalas Beck. São Paulo: Casa do Psicólogo; 2001.

24. Kendall PC, Hollon SD, Beck AT, Hammen $C L$, Ingram RE. Issues and recommendations regarding use of the Beck Depression Inventory. Cognit Ther Res. 1987;11:289-99.

25. Kessler F, Faller S, Souza-Formigoni MLO, Cruz MS, Brasiliano S, Stolf $\mathrm{AR}$, et al. Avaliação multidimensional do usuário de drogas e a Escala de Gravidade de Dependência. Rev Psiquiatr Rio Gd Sul. 2010;32:4856.

26. Santos Cruz M, Andrade T, Bastos FI, Leal E, Bertoni N, Villar LM, et al. Key drug use, health and socio-economic characteristics of young crack users in two Brazilian cities. Int J Drug Policy. 2013;24:432-8.

27. Instituto Brasileiro de Geografia e Estatística (IBGE). Diretoria de pesquisas, coordenação de trabalho e rendimento, pesquisa nacional para amostra de domicílios [Internet]. 2013 [cited 2014 Nov 17]. ibge.gov.br/home/estatistica/populacao/trabalhoerendimento/ pnad2013/

28. Figlie N, Fontes A, Moraes E, Payá R. Filhos de dependentes químicos com fatores de risco bio-psicossociais: necessitam de um olhar especial? Rev Psiquiatr Clin. 2004;31:53-62.

29. Guimarães CF, Santos DVV dos, Freitas RC de, Araújo RB. Perfil do usuário de crack e fatores relacionados à criminalidade em unidade de internação para desintoxicação no Hospital Psiquiátrico São Pedro de Porto Alegre (RS). Rev Psiquiatr Rio Gd Sul. 2008;30:101-8.

30. Lima LAA, Machado DG, Silva FJG Jr, Monteiro CFS. Estratégias utilizadas para o manejo do craving em usuários de crack: revisão integrativa da literatura. Rev Enf UFPI. 2013;2:90-5.

31. van der Meer Sanchez Z, Nappo SA. From the first drug to crack: the sequence of drugs taken in a group of users in the city of São Paulo. Subst Use Misuse. 2007;42:177-88.

32. Duailibi LB, Ribeiro M, Laranjeira R. Perfil dos usuários de cocaína e crack no Brasil. Cad Saude Publica. 2008;24:s545-s57.

33. Vasconcelos SMM, Macedo DS, Lima ISP, Sousa FCF, Fonteles MMF, Viana GSB. Cocaetileno: um metabólito da associação cocaína e etanol. Rev Psiquiatr Clin (São Paulo). 2001;28:207-10.

34. Pérez Prior N, Milara Payá J, Soler Company E, Ferrando Piqueres Raúl, Caja Calvo M, Romero Barco R. Transcendencia del cocaetileno em el consumo combinado de etanol y cocaína. Rev Esp Drogodependencias. 2006;31:254-70.

35. Moura HF, Benzano D, Pechansky F, Kessler FH. Crack/cocaine users show more family problems than other substance users. Clinics (São Paulo). 2014;69:497-9.
36. Zilberman ML, Blume SB. Violência doméstica, abuso de álcool e substâncias psicoativas. Rev Bras Psiquiatr. 2005;27:s51-5.

37. Zaleski M, Laranjeira RR, Marques ACPR, Ratto L, Romano M, Alves HNP, et al. Diretrizes da Associação Brasileira de Estudos do Álcool e outras Drogas (ABEAD) para o diagnóstico e tratamento de comorbidades psiquiátricas e dependência de álcool e outras substâncias. Rev Bras Psiquiatr. 2006;28:142-8.

38. Silva CR da, Kolling NM, Carvalho JCN, Cunha SM da, Kristensen $\mathrm{CH}$. Comorbidade psiquiátrica em dependentes de cocaína/crack e alcoolistas: um estudo exploratório. Aletheia. 2009;30:101-12.

39. Little KY, Krolewaki DM, Zhang L, Cassin BJ. Loss of striatal vesicular monoamine transporter protein (VMAT2) in human cocaine users. Am J Psychiatry. 2003;160:47-55.

40. Diehl A. Tratamento farmacológico de intoxicações agudas e síndrome de abstinência de cocaína. In: Diehl A, Cordeiro DC, Laranjeira R. Tratamentos farmacológicos para dependência química: da evidência científica à prática clínica. Porto Alegre: Artmed; 2010. p. 182-211.

41. Jesus RS, Sangoi RS, Taschetto PL, Brum TF, Piana M, Limberger JB. Perfil farmacoterapêutico de usuários de crack internados em hospital público de Santa Maria-RS. Rev Disciplinarum Scientia. 2014;15:3746.

42. Associação Americana de Psiquiatria. Manual Diagnóstico e Estatístico de Transtornos Mentais, $5^{a}$ edição (DSM-5). Porto Alegre: Artmed; 2014.

43. Marcon SR, Xavier JS, Barcelon AA, Espinosa MM, Barbosa DA. Correlação entre sintomas depressivos e qualidade de vida de usuários de substâncias psicoativas. Rev Esc Enferm USP. 2014;48:663-9.

44. Falck RS, Wang J, Siegal HA, Carlson RG. The prevalence of psychiatric disorder among a community sample of crack cocaine users: an exploratory study with practical implications. J Nerv Ment Dis. $2004 ; 192: 503-7$.

45. Lima, AP. Características do sono e qualidade de vida em dependentes de cocaína [dissertation]. São Paulo: Universidade de São Paulo; 2008.

46. Husband SD, Marlowe DB, Lamb RJ, Iguchi MY, Bux DA, Kirby KC, et al. Decline in self-reported dysphoria after treatment entry in innercity cocaine addicts. J Consult Clin Psychol. 1996;64:221-4.

47. Beck AT, Weissman A, Lester D, Trexler L. The measurement of pessimism: the hopelessness scale. J Consult Clin Psychol. 1974;42:861-5.

48. Minkoff K, Bergman E, Beck A, Beck R. Hopelessness, depression, and attempted suicide. Am J Psychiatry. 1973;130:455-9.

49. Silveira C, Meyer C, Souza GR, Ramos MO, Souza MC, Monte FG, et al. Qualidade de vida, autoestima e autoimagem dos dependentes químicos. Cienc Saude Coletiva. 2013;18:2001-6.

\section{Correspondence:}

Joana Corrêa de Magalhães Narvaez

Hospital de Clínicas de Porto Alegre, Serviço de Psicologia

Rua Ramiro Barcelos, 2350

90035-903 - Porto Alegre, RS - Brazil

Tel.: + 55 (51) 3359.8507

E-mail: jnarvaez@hcpa.edu.br 